\title{
Influence of spray-drying conditions on the physicochemical properties of red-fleshed dragon fruit (Hylocereus polyrhizus) powder made from peel and flesh
}

\author{
Trang T. N. Tran, Quan A. Do, Ngoan H. Nguyen, Tram N. Pham, Trang L. H. Do, \\ Diep T. N. Duong*, \& Binh Q. Hoang
}

Faculty of Chemical Engineering and Food Technology, Nong Lam University, Ho Chi Minh City, Vietnam

\begin{tabular}{|c|c|}
\hline $\mathrm{O}$ & ABSTRACT \\
\hline $\begin{array}{l}\text { Keywords } \\
\text { Physicochemical } \\
\text { Pitaya } \\
\text { Powder } \\
\text { Spray-drying } \\
\text { *Corresponding author } \\
\text { Duong Thi Ngoc Diep } \\
\text { Email: duongngocdiep@hcmuaf.edu. }\end{array}$ & $\begin{array}{l}\text { Pitaya production has been increasing, that offers abundant } \\
\text { material for food processing. New product development would } \\
\text { greatly add value for this produce. The present study focused on } \\
\text { the effects of spray-drying conditions such as coating material } \\
\text { concentration and spray-drying temperature on the physic- } \\
\text { ochemical characteristics of red-fleshed dragon fruit powder } \\
\text { made from peel and flesh. The sample quality was influenced } \\
\text { by two experimental factors, which were the maltodextrin con- } \\
\text { centration and the spray-drying inlet temperature. The samples } \\
\text { spray-dried at } 140^{\circ} \mathrm{C} \text { to } 150^{\circ} \mathrm{C} \text { with } 15 \% \text { maltodextrin (w/w) } \\
\text { gave the powder with the highest betacyanin, polyphenol, and } \\
\text { vitamin C retention results }(97.62-98.86 \% \text {, } 90.66-91.63 \% \text {, } \\
\text { and } 63.40-63.68 \% \text {, respectively). The moisture content, water } \\
\text { activity and solubility of the sample was } 3.88 \% \text { to } 4.27 \% \text {, } \\
0.26 \text { to } 0.28 \text { and } 99 \% \text {, respectively. Red-fleshed dragon fruit } \\
\text { powder made from flesh and peel has numerous potentials in } \\
\text { the beverage industry. }\end{array}$ \\
\hline$\left(\begin{array}{ll}1 & 1 \\
\end{array}\right.$ & 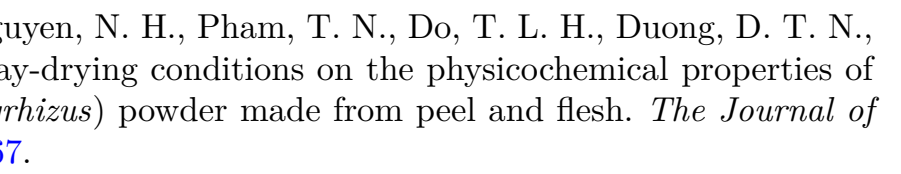 \\
\hline
\end{tabular}

\section{Introduction}

Red-fleshed dragon fruit, also known as red pitaya, is a member of the Cactaceae family and the order of Caryophyllales. With the specific purple-red color of the peel and flesh, delicate and appetizing flavor, high nutritional and functional potentials (Stintzing et al., 2003), redfleshed dragon fruits are widely cultivated on a large scale throughout countries that possess tropical and subtropical climate, including Vietnam. Red-fleshed dragon fruit is well-known for its outstanding pharmacological benefits. Both the flesh and peel are rich in polyphenol and antioxidants, with the peel exhibiting higher antioxidant activities (Wu et al., 2006). Although the ideal weather pattern can benefit the cultivation of such fruit, it still leaves some negative effects on other related aspects as the fruit is usually consumed fresh, including difficulties regarding storage conditions and transportation, etc. For that reason, processes that can turn fresh fruits into commercialized products play an important role in building up the values for agricultural commodities. Fruit powder is an excellent option in response to the trend towards healthier and more natural products for consumers. The quality of the product will hardly reach the requirement if the processing is not controlled well. Because of this, the study utilized peel as an alternative source to partly replace the flesh in making red dragon fruit powder by spray-drying, thus reduce 
the loss of by-products and lower the price of the finish powder. The present research was carried out to assess the physicochemical properties of pitaya fruit powder with emphasis on the physicochemical properties of water activity, moisture content, solubility, etc. by varying concentrations of the coating materials (maltodextrin) and inlet temperatures of spray drying.

\section{Materials and Methods}

\subsection{Materials}

Red-fleshed pitaya used in the present study was purchased locally from Thu Duc wholesale market in Ho Chi Minh City within a week of harvesting. The selected fruits were fresh and ripe, with no defect of physical injures and fungi (Figure 1). One standardized fruit weighed approximately $450 \mathrm{~g}$ with the ratio of flesh: peel equaled 4:1. The Brix values of the peel and flesh were $5.0^{\circ} \mathrm{Bx}$ and $12^{\circ} \mathrm{Bx}$ respectively. The $\mathrm{pH}$ values for flesh and peel were 4.58 and 4.94, respectively. The betacyanin, ascorbic acid, and total phenolic contents were $12.74 \mathrm{mg} / 100 \mathrm{~g}, 16.25 \mathrm{mg} \mathrm{AA} / 100$ $\mathrm{g}$, and $57.29 \mathrm{mg} \mathrm{GAE} / 100 \mathrm{~g}$ in the flesh, respectively and were $3.75 \mathrm{mg} / 100 \mathrm{~g}, 10.63 \mathrm{mg} \mathrm{AA} / 100$ $\mathrm{g}$, and $25.25 \mathrm{mg} \mathrm{GAE} / 100 \mathrm{~g}$ in the peel, respectively. The peel, flesh, and scale (the prominent, green parts located on the fruit's skin) were separated and stored at $-18^{\circ} \mathrm{C}$ until use.

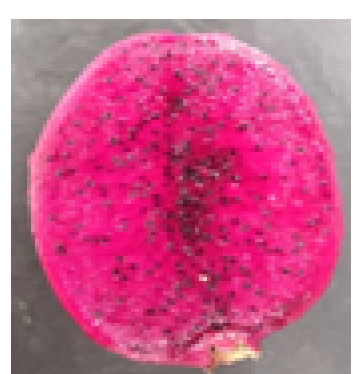

A

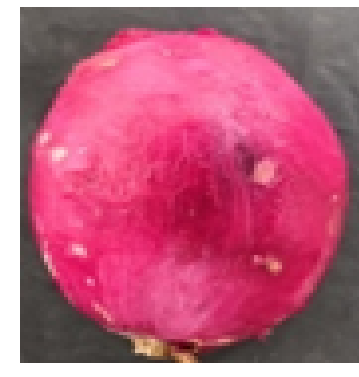

B
Figure 1. (A) Flesh and (B) peel of red dragon fruit.

Enzyme Pectinex Ultra SP-L liquid was produced by Novozymes group (Bagsvaerd, Denmark), distributed by Brenntag Vietnam Company Limited (Ho Chi Minh City). Enzyme pectinase is an enzyme of the polygalacturonase group. The enzyme has its activity of 3800 PGNU per $\mathrm{mL}$ (polygalacturonase activity per $\mathrm{mL}$ ). Enzyme is stored at $10-12^{\circ} \mathrm{C}$. The activity of this product is stable over wide $\mathrm{pH}(2.8-6.5)$ and temperature $\left(15-55^{\circ} \mathrm{C}\right)$ ranges.

Chemicals: gallic acid 99\%, folin-ciocalteu 99\%, ascorbic acid 99,7\% (Merck, Germany), sodium carbonate $98 \%$, sodium metabisulfite, citric acid anhydrous, disodium hydrogen phosphate, iodine, potassium iodide (Xilong, China), ethanol 99\% (Chemos, Vietnam), maltodextrin DE 10 (Himedia, India).

Equipment: electronic scale (Ohaus Corp.pine Brook, USA), water bath (Schutzart, Germany), balances (Sartorius, Japan), vortex, UV-vis spectrophotometer (Jenway, USA), spray-dryer KD400 (Vietnam), blender (Phillip, Netherland), juicer (Vietnam), Z206A centrifuge (Hermle, Germany), IKA T18 digital Ultra Turrax homogenizer (IKA, Germany), Chroma meter CR-400 (Konica Minolta, Japan).

\subsection{Sample preparation}

\subsubsection{Flesh extract preparation}

The flesh after thawing was ground by a juicer to eliminate the seeds then mixed with water to the ratio of 1:1 $(\mathrm{w} / \mathrm{w})$. Pectinex Ultra SPL of $0.2 \%(\mathrm{w} / \mathrm{w})$ concentration was added. The puree was hydrolyzed at $45^{\circ} \mathrm{C}$ for $60 \mathrm{~min}$ (a result of the preliminary test). After that, the sample was inactivated at $100^{\circ} \mathrm{C}$ for $1 \mathrm{~min}$, then filter through cheesecloth. The obtained solution was stored at $10^{\circ} \mathrm{C}$ until use.

\subsubsection{Peel extract preparation}

The peel was mixed with water to the ratio of 1:1 (w/w) and crushed by a blender. Pectinex Ultra SPL of $0.4 \%(\mathrm{w} / \mathrm{w})$ concentration was added to the peel solution. The puree was hydrolyzed at $45^{\circ} \mathrm{C}$ for $120 \mathrm{~min}$ (a result of the preliminary test). After that, the sample was inactivated at $100^{\circ} \mathrm{C}$ for $1 \mathrm{~min}$, then centrifuged at $5000 \mathrm{rpm}$ for $10 \mathrm{~min}$ and filtrated through a 102-filter paper with a diameter pore of $15-20 \mu \mathrm{M}$ to get the peel extract. The obtained solution was refrigerated at $10^{\circ} \mathrm{C}$ until use.

\subsubsection{Powder preparation}

The extracts of flesh and peel puree were mixed to the ratio of $4: 1(\mathrm{w} / \mathrm{w})$, this ratio was obtained based on the natural proportion between flesh and de-scaled peel of standardized red-fleshed 
dragon fruit. The mixture was added with different concentrations of maltodextrin and homogenized at $5000 \mathrm{rpm}$ for $5 \mathrm{~min}$. The sample was dried at $150^{\circ} \mathrm{C}$ in a spray-dryer KD-400 equipped with a diameter nozzle in the Chemical Department of Nong Lam University, Ho Chi Minh City, as the feed flow rate of $500 \mathrm{~mL} / \mathrm{h}$ was controlled by the pump rotation speed at $2.5 \mathrm{rpm}$ and compressor air pressure of $2.1 \mathrm{kgf} / \mathrm{cm}^{2}$. The powder samples were stored in a screw-capped amber bottle at $-18^{\circ} \mathrm{C}$ until further analysis.

\subsection{Experiment design}

\subsubsection{Effect of maltodextrin concentration on physico-chemical of powder}

This experiment was investigated by an experimental single factor. Maltodextrin concentration with 3 levels $(10 \%, 15 \%$, and $20 \%$, w/w) was surveyed. Sample preparation was followed in section 2.2. The physicochemical properties of powder including betacyanin retention, total phenolic content retention, vitamin $\mathrm{C}$ retention, moisture content, water activity, solubility, $\mathrm{L}^{*}, \mathrm{C}$, and $\mathrm{H}^{\circ}$ were recorded.

\subsubsection{Effect of drying temperature on physic- ochemical of powder}

After the maltodextrin concentration was chosen (section 2.3.1), inlet air temperature with 3 levels $\left(140,150\right.$, and $\left.160^{\circ} \mathrm{C}\right)$ was investigated. Sample preparation was followed section 2.2. The physicochemical properties of powder were including betacyanin retention, total phenolic content retention, vitamin $\mathrm{C}$ retention, moisture content, water activity, solubility, $\mathrm{L}^{*}, \mathrm{C}$, and $\mathrm{H}^{\circ}$ recorded.

\subsubsection{Analytical methods}

Moisture Content: The moisture was determined by infrared moisture drying balance MX$50(0.01 \% / \max 51 \mathrm{~g})$, Sartorius, Japan. One gram of sample was weighed and dried until a constant weight was obtained.

Water Activity: The water activity was determined by using a water activity meter AquaLabDewPoint 4Te (Decagon Devices Inc., Pullman, WA, USA) at $25^{\circ} \mathrm{C} \pm 0.5$.

Color measurement: The color of the pitaya powder was measured by using a Chroma meter
CR-400 (Konica Minolta, Japan). The lens of the color reader was put upon the powder to obtain the $\mathrm{L}^{*}, \mathrm{C}$, and $\mathrm{H}^{\mathrm{O}}$ values for the powder.

Solubility: The water solubility was performed using the method described by Reddy et al. (2015) with a few modifications. A sample of $0.5 \mathrm{~g}$ was mixed with $6 \mathrm{~mL}$ of distilled water and then centrifuged at $5000 \mathrm{rpm}$ for $10 \mathrm{~min}$. After centrifugation, the suspension was placed in a dish and dried at $105^{\circ} \mathrm{C}$ for $4 \mathrm{~h}$ to obtain constant dry solids weight. The solubility (\%) was determined as:

$$
\text { Solubility }(\%)=\frac{\text { Weight of dry solids in the supernatant }}{\text { Weight of dry sample }} \times 100
$$

Total betacyanin content: The total betacyanin content of the dragon fruit sample was determined by a colorimetric method (Rebecca et al., 2008). The sample was weighed and diluted in water, followed by vortexing, then centrifuged at $5000 \mathrm{rpm}$ for $10 \mathrm{~min}$. The supernatant was collected and filtrated using filter paper. The absorption value was analyzed by a spectrophotometer (Spectronic UV-Vis Genesys 10S Thermo, USA) at a wavelength of $538 \mathrm{~nm}$. The proportion of betacyanin retention: $=\left(\mathrm{BC}_{1} / \mathrm{BC}_{0}\right.$ )$\times 100$, where $\mathrm{BC}_{1}$ is the betacyanin content after spray-dried, $\mathrm{BC}_{0}$ is the betacyanin content before the spray-dried interval.

Total phenolic content: Polyphenols in red dragon fruits were determined by the FolinCiocalteau method (Singleton et al., 1999). In a tube, $1 \mathrm{~mL}$ of distilled water was mixed well with $1 \mathrm{~mL}$ of the diluted sample and $0.5 \mathrm{~mL}$ of FolinCiocalteau $10 \%$ and left for $6 \mathrm{~min}$. Continue to add $1.5 \mathrm{~mL}$ of $20 \% \mathrm{Na}_{2} \mathrm{CO}_{3}$ and $1 \mathrm{~mL}$ of distilled water, then left for another $2 \mathrm{~h}$ in darkness. The absorption value was analyzed by a spectrophotometer at a wavelength of $760 \mathrm{~nm}$. The total phenolic content was calculated based on the standard curve for polyphenols and expressed by GAE/100 g dry solid. Proportion TPC retention: $=\left(\mathrm{TPC}_{1} / \mathrm{TPC}_{0}\right) \times 100$, where $\mathrm{TPC}_{1}$ is the total phenolic content after spray-dried, $\mathrm{TPC}_{0}$ is the total phenolic content before spray-dried interval.

Ascorbic acid content (UV-VIS method): The method used to determine total ascorbic acid content was described by Kapur et al. (2012). In a tube, $0.23 \mathrm{~mL}$ of $3 \%$ bromine water was added into $4 \mathrm{~mL}$ of sample solution, $0.13 \mathrm{~mL}$ of $10 \%$ thiourea. Then $1 \mathrm{~mL}$ of 2, 4-DNPH solution was added. Samples were kept at $37^{\circ} \mathrm{C}$ temperature for $3 \mathrm{~h}$ in a water bath. After that, samples were 
cooled in an ice bath for 30 min and treated with $5 \mathrm{~mL}$ chilled $85 \% \mathrm{H}_{2} \mathrm{SO}_{4}$. The absorption value was analyzed by a spectrophotometer at a wavelength of $521 \mathrm{~nm}$. The total ascorbic content was calculated based on the standard curve for ascorbic acid and expressed by AAE/100 g dry solid. Proportion $\mathrm{AAC}$ retention $=\left(\mathrm{AAC}_{1} / \mathrm{AAC}_{0}\right) \times$ 100 , where $\mathrm{AAC}_{1}$ is the total ascorbic acid content after spray-dried, $\mathrm{AAC}_{0}$ is the total ascorbic acid content before spray-dried interval.

Ascorbic acid content (HPLC method): The method followed Uckoo et al. (2011) with some modifications. In a tube, an aliquot of $0.5 \mathrm{~g}$ powder sample was homogenized (8000rpm, $1 \mathrm{~min}$ ) in $3 \%$ metaphosphoric acid. The supernatant was diluted with ortho-phosphoric acid $3 \mathrm{mM}$ and filtered through a $0,45 \mu \mathrm{M}$ PTFE membrane. The HPLC operation systems (LC-20AD, Shimadzu, Japan) including pump (SIL-20A), detector (UVVIS SPD-20A), degasser (DGU-20A3). The mobile phase A was provided with ortho-phosphoric acid $3 \mathrm{mM}$ and the stationary phase was column C18 reverse (Inertsil, ODS 3, Japan). An isocratic mobile phase was run at a flow rate of $1.0 \mathrm{~mL} / \mathrm{min}$. An injection volume of $1.0 \mu \mathrm{L}$ was used. The ascorbic acid was detected at $254 \mathrm{~nm}$.

\subsection{Statistical analysis}

All experiments were carried out 2 times. Data and results were analyzed by using JMP 10.0 software and $\mathrm{p}$-value $(P<0.05)$ and ANOVA Oneway analysis of variance (ANOVA) to determine the significant differences $(P<0.05)$ between the means. Results are presented as mean \pm standard deviation.

\section{Results and Discussion}

\subsection{Effect of maltodextrin concentration on physicochemical of powder}

The results of this experiment were as listed in Table 1.

Overall, all values of antioxidant compounds increased with maltodextrin concentration from $10 \%$ to $15 \%$ and decreased with maltodextrin concentration from $15 \%$ to $20 \%$ (Figure 2). The highest values of betacyanin, polyphenol, and vitamin $\mathrm{C}$ were obtained at $15 \%$ maltodextrin concentration $(98.73 \%, 97.35 \%$, and $63.73 \%$, respectively). This can be explained by the protective ability of maltodextrin as a coating material to- wards sensitive compounds like antioxidants, but if the maltodextrin concentration was too high, it increased the viscosity of the feed solution and reduced the efficiency of the spray-drying process. All samples had similar values of moisture content $(4.07-4.99 \%)$, water activity (0.26 - 0.28), and solubility $(99.13-99.94) . \mathrm{L}^{*}$ value of the sample with $20 \%$ maltodextrin concentration was higher and significantly different $(P<0.05)$ from the other two samples.

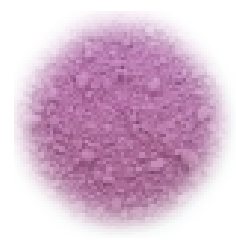

A

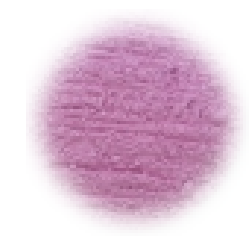

B

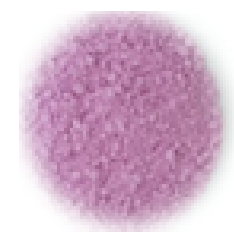

C
Figure 2. Spray-dried powder with (A) 10\%, (B) $15 \%$, and (C) $20 \%$ maltodextrin concentration supplement.

$\mathrm{C}$ and $\mathrm{H}^{\circ}$ values between the three samples were not significantly different from each other $(P<0.05)$. An increase in $\mathrm{L}^{*}$ values $(72.97-$ $76.45)$ and a decrease in Chroma values $(30.38$ - 28.24) were observed while $\mathrm{H}^{\circ}$ remained stable (approximately 359.77). This result indicated that all samples almost had the same light purplered color and the color intensity got lighter as the maltodextrin concentration increased from 10\% to $20 \%$. This can be explained by the influence of the white color of maltodextrin on the color of the samples, the higher the concentration of maltodextrin, the lighter the color of the powder samples. The sample with $15 \%$ maltodextrin concentration had the highest physicochemical properties.

\subsection{Effect of drying temperature on physico- chemical of powder}

In general, the increase in temperature from $140^{\circ} \mathrm{C}$ to $150^{\circ} \mathrm{C}$ witnessed an increase in physicochemical properties, with betacyanin retention increased from $97.62 \%$ to $98.76 \%$, polyphenol retention increased from $98.19 \%$ to $98.31 \%$ and vitamin $\mathrm{C}$ retention increased from $63.40 \%$ to $63.68 \%$ (Table 2). However, when the drying temperature continued increasing, the physicochemical values started to drop, at this time the betacyanin retention, polyphenol retention, vitamin C retention were $95.63 \%, 92.42 \%$, and $58.63 \%$, re- 
Table 1. Effect of maltodextrin concentration on physicochemical properties of redfleshed dragon fruit powder

\begin{tabular}{lccc}
\hline \multirow{2}{*}{ Attributes } & \multicolumn{3}{c}{ Maltodextrin concentration (\%) } \\
\cline { 2 - 4 } & \multicolumn{1}{c}{10} & 15 & 20 \\
\hline Betacyanin retention (\%) & $74.39^{\mathrm{c}} \pm 0.34$ & $98.73^{\mathrm{a}} \pm 0.18$ & $84.87^{\mathrm{b}} \pm 0.63$ \\
Polyphenol retention (\%) & $83.24^{\mathrm{b}} \pm 0.29$ & $97.35^{\mathrm{c}} \pm 0.60$ & $96.92^{\mathrm{c}} \pm 0.47$ \\
Vitamin C retention (\%) & $59.42^{\mathrm{b}} \pm 0.62$ & $63.73^{\mathrm{a}} \pm 1.31$ & $63.32^{\mathrm{ab}} \pm 1.80$ \\
Moisture content (\%) & $4.99^{\mathrm{a}} \pm 0.16$ & $4.13^{\mathrm{b}} \pm 0.79$ & $4.07^{\mathrm{b}} \pm 0.07$ \\
Water activity & $0.28^{\mathrm{a}} \pm 0.01$ & $0.26^{\mathrm{a}} \pm 0.01$ & $0.28^{\mathrm{a}} \pm 0.02$ \\
Solubility (\%) & $99.13^{\mathrm{a}} \pm 0.95$ & $99.94^{\mathrm{a}} \pm 1.52$ & $99.45^{\mathrm{a}} \pm 1.48$ \\
$\mathrm{~L}^{*}$ & $72.97^{\mathrm{a}} \pm 0.39$ & $73.24^{\mathrm{a}} \pm 0.85$ & $76.45^{\mathrm{b}} \pm 0.01$ \\
$\mathrm{C}$ & $30.38^{\mathrm{a}} \pm 0.48$ & $30.16^{\mathrm{a}} \pm 0.70$ & $28.24^{\mathrm{a}} \pm 0.82$ \\
$\mathrm{H}^{\mathrm{o}}$ & $359.76^{\mathrm{a}} \pm 0.33$ & $359.78^{\mathrm{a}} \pm 0.54$ & $359.76^{\mathrm{a}} \pm 0.64$ \\
\hline a, b, Denote the statistically significant difference at $P<0.05 . \mathrm{N}=2$.
\end{tabular}

Table 2. Effect of inlet temperature on physicochemical properties of red-fleshed dragon fruit powder

\begin{tabular}{lccc}
\hline \multirow{2}{*}{ Attributes } & \multicolumn{3}{c}{ Inlet temperature $\left({ }^{\circ} \mathrm{C}\right)$} \\
\cline { 2 - 4 } & 970 & 150 & 160 \\
\hline Betacyanin retention (\%) & $97.62^{\mathrm{a}} \pm 0.85$ & $98.76^{\mathrm{a}} \pm 0.28$ & $95.63^{\mathrm{b}} \pm 0.43$ \\
Polyphenol retention (\%) & $98.19^{\mathrm{a}} \pm 0.74$ & $98.31^{\mathrm{a}} \pm 0.12$ & $92.42^{\mathrm{b}} \pm 0.70$ \\
Vitamin C retention (\%) & $63.68^{\mathrm{a}} \pm 0.15$ & $63.40^{\mathrm{a}} \pm 0.64$ & $58.63^{\mathrm{b}} \pm 0.55$ \\
Moisture content (\%) & $4.27^{\mathrm{a}} \pm 0.86$ & $3.88^{\mathrm{a}} \pm 0.09$ & $3.29^{\mathrm{a}} \pm 0.04$ \\
Water activity & $0.26^{\mathrm{a}} \pm 0.02$ & $0.28^{\mathrm{a}} \pm 0.06$ & $0.28^{\mathrm{a}} \pm 0.07$ \\
Solubility (\%) & $99.03^{\mathrm{a}} \pm 1.26$ & $98.72^{\mathrm{a}} \pm 0.91$ & $99.13^{\mathrm{a}} \pm 1.03$ \\
$\mathrm{~L}^{*}$ & $72.97^{\mathrm{a}} \pm 0.34$ & $72.21^{\mathrm{a}} \pm 0.37$ & $72.57^{\mathrm{a}} \pm 0.45$ \\
$\mathrm{C}$ & $31.85^{\mathrm{a}} \pm 0.38$ & $32.37^{\mathrm{a}} \pm 0.44$ & $33.04^{\mathrm{a}} \pm 0.21$ \\
$\mathrm{H}^{\mathrm{o}}$ & $359.75^{\mathrm{a}} \pm 0.01$ & $359.76^{\mathrm{a}} \pm 0.01$ & $359.74^{\mathrm{a}} \pm 0.01$ \\
\hline a, b, ${ }^{\circ}$ Denote the statistically significant difference at $P<0.05 . \mathrm{N}=2$.
\end{tabular}

spectively. This phenomenon occurred due to the sensitivity of polyphenol compounds over temperature. High temperature can easily destroy product's components that are not heat-resistant, thus leads to the decrease of these values. The drying temperature increased (from $140^{\circ} \mathrm{C}$ to $160^{\circ} \mathrm{C}$ ) leaded to a decrease in moisture content $(4.27-3.29 \%)$ (Figure 3). However, this range of temperature showed slightly no change in water activity $(0.26-0.28)$ and solubility (98.72 - 99.13\%). $\mathrm{L}^{*}, \mathrm{C}$, and $\mathrm{H}^{\circ}$ values between three samples were not significantly different from each other $(P<0.05)$. This result indicated that inlet drying temperature did not show any influences on the color of the powder. The samples spray-dried at $140^{\circ} \mathrm{C}$ and $150^{\circ} \mathrm{C}$ had the highest physicochemical properties.

Analytical results by HPLC showed that the samples analyzed (experiment 2.3.2) had peak area decreasing in the direction of increasing drying temperature, this showed that the vitamin $\mathrm{C}$

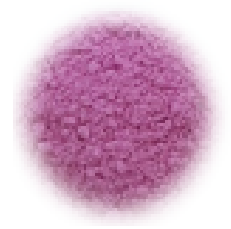

A

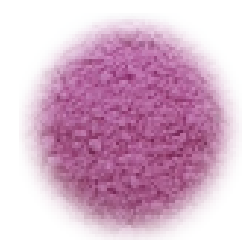

B

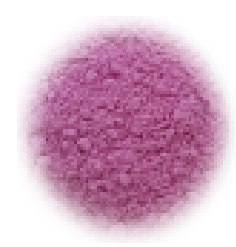

C
Figure 3. Powder spray-dried at (A) $140^{\circ} \mathrm{C}$, (B) $150^{\circ} \mathrm{C}$, and $(\mathrm{C}) 160^{\circ} \mathrm{C}$.

content in samples decreased gradually with the increasing of drying temperature (Figure 4). This result is consistent with the result obtained from UV-VIS analysis. Thus, analysis attributes such as betacyanin content, total phenolic content, ascorbic acid content by UV-VIS spectroscopy method are acceptable and still show the impact on the experimental factors of the physicochemical properties of dragon fruit powder. 


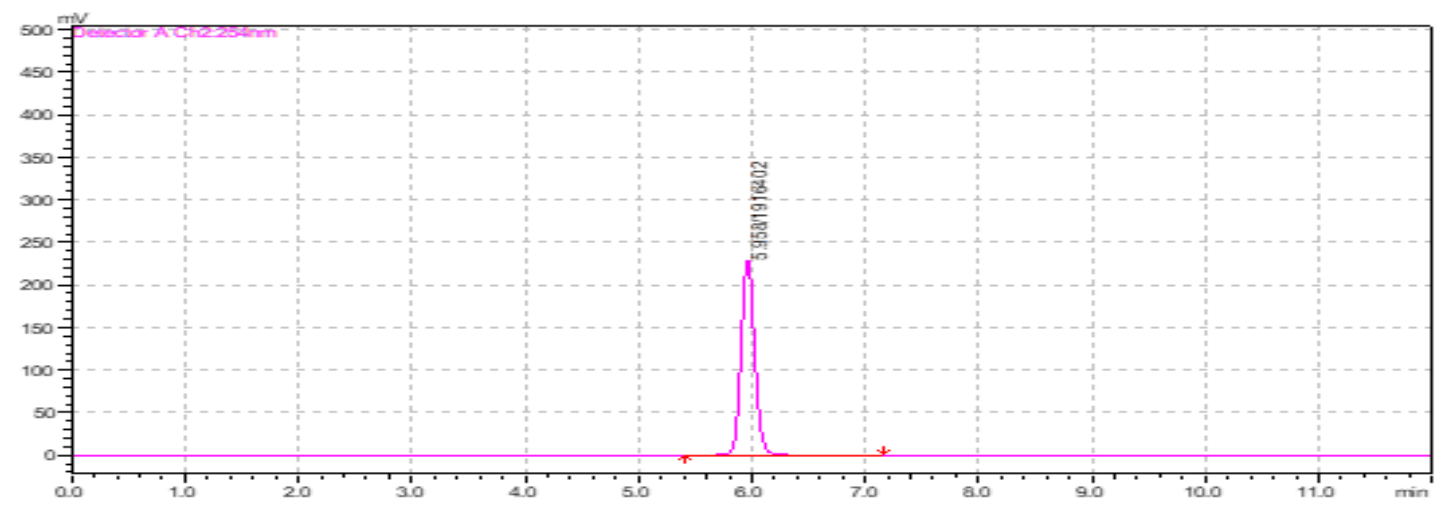

The peak of standard ascorbic acid.

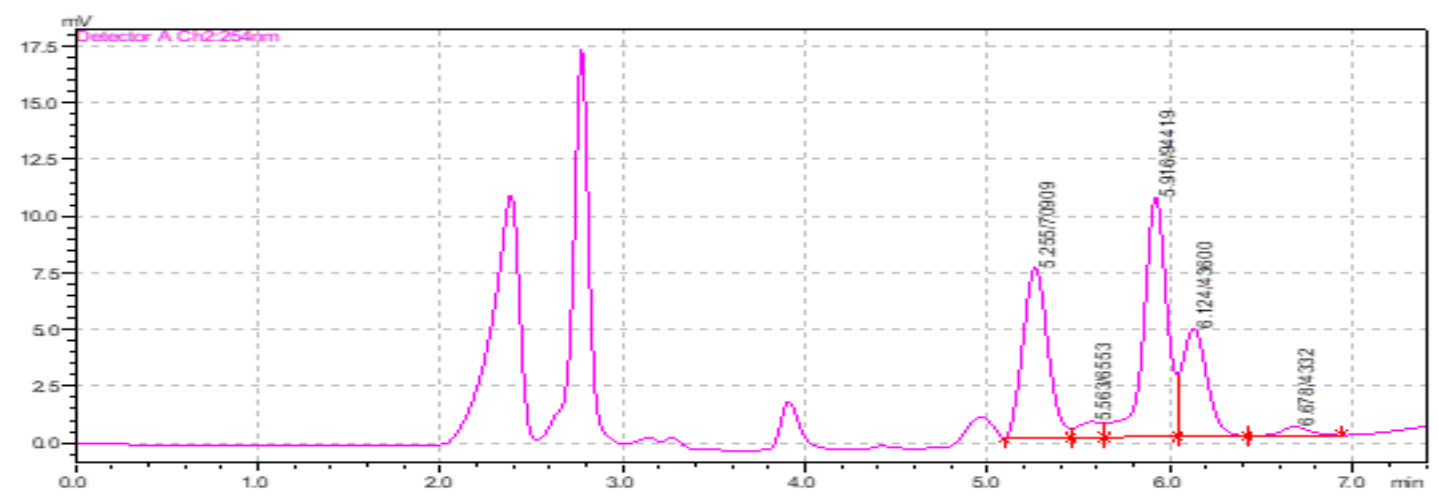

The peak of ascorbic acid of powder spray-dried at $140^{\circ} \mathrm{C}$.

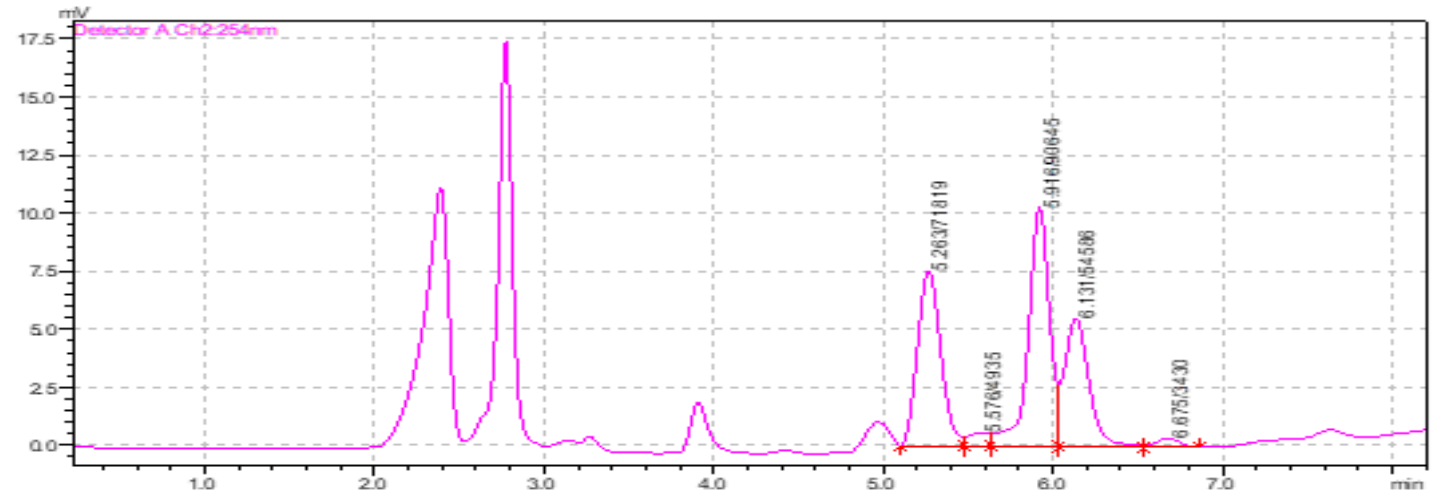

The peak of ascorbic acid of powder spray-dried at $150^{\circ} \mathrm{C}$

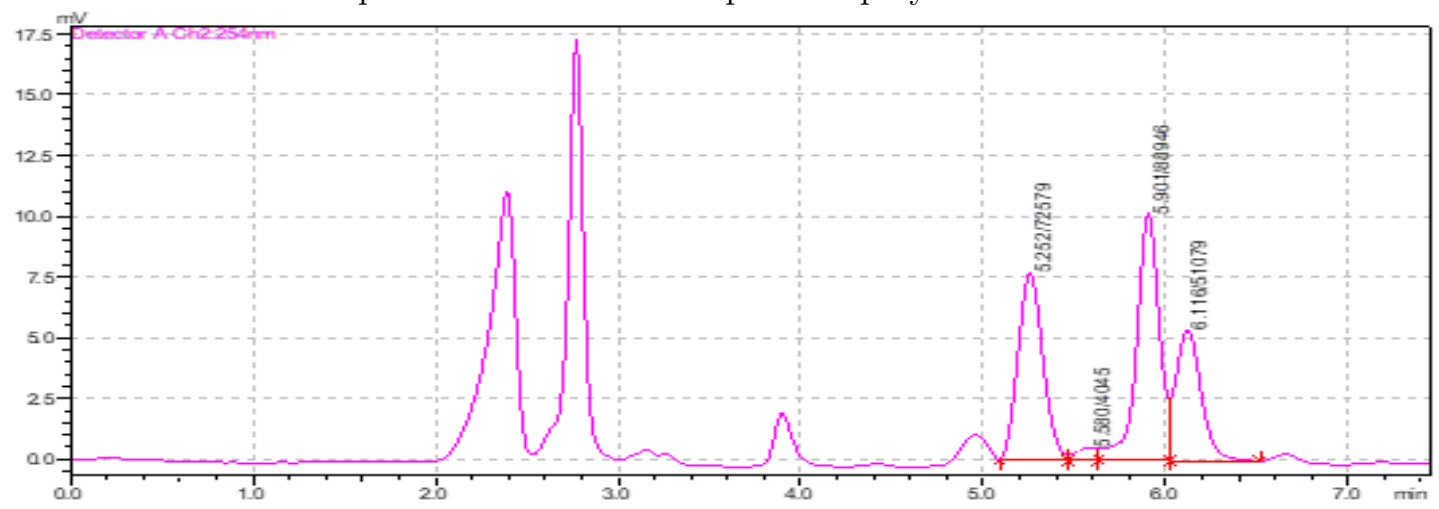

The peak of ascorbic acid of powder spray-dried at $160^{\circ} \mathrm{C}$.

Figure 4. The peaks of ascorbic acid of samples under different drying temperatures. 


\section{Conclusions}

The physicochemical properties such as betacyanin retention, polyphenol retention, and vitamin $\mathrm{C}$ retention varied depending on the maltodextrin concentration and inlet spray-drying temperature. Moisture content also showed variations. However, water activity and solubility did not show any significant changes in values between samples with different maltodextrin concentrations or inlet spray-drying temperatures. Moreover, unlike $\mathrm{C}$ and Ho values which remained stable under different maltodextrin concentrations and inlet temperatures, $\mathrm{L}^{*}$ value of samples with $20 \%$ maltodextrin concentration was significantly higher than the other samples. The best spray-drying conditions in relation to physicochemical properties of the powder were $140^{\circ} \mathrm{C}$ to $150^{\circ} \mathrm{C}$ inlet temperature and $15 \%$ maltodextrin concentration, with $97.62-98.76 \%$ betacyanin retention, 98.19 - $98.31 \%$ polyphenol retention, 63.40 - $63.68 \%$ vitamin C retention, $3.88-4.27 \%$ moisture content, 72.21 - 72.97 in $L^{*}$ value. Spraydrying is a convenient method to process redfleshed dragon fruit into powder. Maltodextrin is also a good coating material to protect sensitive constituent components. Further recommendations include more research on the ratio of the peel and flesh solution before spray-drying or using other materials as microencapsulating agents to optimize the value of the powder.

\section{Acknowledgments}

The authors would like to thank Nong Lam University, Ho Chi Minh City for sponsoring our research (project number: CS-SV19-CNTP-03).

\section{References}

Kapur, A., Hasković, A., Čopra-Janićijević, A., Klepo, L., Topčagić, A., Tahirović, I., \& Sofić, E. (2012). Spectrophotometric analysis of total ascorbic ccid content in various fruits and vegetables. Bulletin of the Chemists and Technologists of Bosnia and Herzegovina 38, 39-42.

Rebecca, O. P. S., Zuliana, R., Boyce, A. N., \& Chandran, S. (2008). Determining pigment extraction efficiency and pigment stability of dragon fruit (Hylocereus polyrhizus). Journal of Biological Sciences 8(7), 1174-1180.

Reddy, C. K., Pramila, S., \& Haripriya, S. (2015). Pasting, textural and thermal properties of resistant starch prepared from potato (Solanumtuberosum) starch using pullulanase enzyme. Journal of Food Science and Technology 52(3), 1594-1601

Singleton, V. L., Orthofer, R., \& Lamuela-Raventós, R. M. (1999). Analysis of total phenols and other oxidation substrates and antioxidants by means of folinciocalteu reagent. In Minor, D. L., \& Colecraft, H. M. (Eds.). Methods in Enzymology (152-178). Massachusetts, USA: Academic Press.

Stintzing, F. C., Schieber, A., \& Carle, R. (2003). Evaluation of colour properties and chemical quality parameters of cactus juices. European Food Research and Technology 216, 303-311.

Uckoo, R. M., Jayaprakasha, G. K., Nelson, S. D., \& Patil, B. S. (2011). Rapid simultaneous determination of amines and organic acids in citrus using highperformance liquid chromatography. Talanta 83(3), 948-954.

Wu, L. C., Hsu, H. W., Chen, Y. C., Chiu, C. C., Lin, Y. I., \& Ho, J. A. A. (2006). Antioxidant and antiproliferative activities of red pitaya. Food Chemistry 95(2), 319-327. 